\title{
Simple utilization of lactic acid whey in dairy processing
}

\author{
J. Csanádi \\ e-mail: csanadi@mk.u-szeged.hu
}

\author{
G. Szász \\ O. H-Bara \\ e-mail: tabrika88@hotmail.com \\ e-mail: otti@mk.u-szeged.hu
}

\author{
University of Szeged, \\ Faculty of Food Engineering, \\ Department of Food Engineering, \\ 6724 Szeged, Mars Sq. 7. Hungary
}

\begin{abstract}
The use of ultra-filtered lactic acid whey retentate was investigated for the making of sour cream. The utilization of lactic acid whey is limited due to its special properties, so the logical utilization way is to use it in fermented products. First, we concentrated lactic acid whey collected from cottage cheese making by ultrafiltration (UF), then UF Whey Retentate (UFWR) was added (by 2, 5, and 10\%) into fat standardized cream for sour cream making. We investigated the texture and sensory properties of the sour cream samples compared with the industrial products. Generally, we can state that the use of small portion of UF whey retentate did not result noticeable changes and did not reduce the sensory value of sour creams. Higher UF whey retentate addition improved some texture properties of experimental samples, but the summarized evaluation of UFWR addition was not unequivocal. Control samples showed better results. Based on our results, the sample, which contained $5 \%$ UF whey retentate, had good texture and acceptable sensory properties. Furthermore, more than $5 \%$ UF lactic acid whey retentate (coming from our own ultrafiltration process) resulted remarkably
\end{abstract}

Keywords and phrases: whey utilization, sour cream, ultrafiltration 
worse sensory properties than the other samples. Further investigation is needed to find the optimal composition and sensory properties of UFWR. Furthermore, we have to perform technological investigation to reach a higher concentration factor using pre-treatment of whey and to avoid the precipitation of whey proteins during the high temperature pasteurization of cream, cream mixed with UFWR or diafiltered whey retentate. We guess that the use of one-stage diafiltration would already decrease the unfavourable sensory properties of lactic acid whey retentate.

\section{Introduction}

A major part, actually $65-90 \%$, of milk becomes side products (or waste) in cheese and casein production. By some estimation, 62 billion litres of whey are produced each year world-wide (Malkovic, 2015), causing significant problems for producers considering environmental aspects. But whey contains valuable organic compounds (as proteins, lactose, and fat) and minerals. Actually, the beneficial effect of whey proteins and other compounds on human health are well-known (Squadrito et al., 2000; Ha \& Zemel, 2003; Bhathena \& Velasquez, 2002; Seppo et al., 2003; Hayes \& Cribb, 2008; Fanti et al., 2006; Chen \& Reimer, 2009; Tahavorgar et al., 2015).

Therefore, this extremely huge amount of whey is a big problem and there is need to reduce its polluting effect and to produce valuable products. By today, the utilization of whey has arrived to the separation and purification of different special compounds from the simple use as the feed for animals. Whey proteins and serum proteins seem to be the most valuable components of whey, but the other compounds are also good raw materials (e.g. lactose) for further utilization. The simplest utilization is to produce flavoured whey drinks as "Riska Shake" produced by Alföldi Tej Ltd., Hungary. But, usually the sensory properties, low $\mathrm{pH}$ and the low solid content make whey difficult to use it in other products. Consequently, the taste and smell ameliorate, and the reducing of moisture content can open up new perspectives for the lactic acid whey utilization.

Many researchers published results of the different membrane filtration techniques used for whey concentration (Brennan et al., 2006; Walstra et al., 2006; Román et al., 2009; Hodúr et al., 2010; Szélpál et al., 2014; Schwinden Prudencio et al., 2014). Very important results were published related to the enhancement of membrane techniques to reach higher efficiency and to the removal of lactic acid from lactic acid whey (Chen et al., 2016). This objective can be reached with the use of vibration (Kertész et al., 2010), with sonication 
(Gajendragadkar \& Gogate, 2016), with electrical methods (Almecija et al., 2009; Corbatón-Báguena et al., 2016), with diafiltration, or with optimization of the condition of the filtration (Román et al., 2011). As a result of the development of whey membrane filtration process, many forms of utilization can be adopted in the food and medicine industry. There are many results published in different area (including the use of lactic acid whey) such as the purification of whey proteins (Chandrapala et al., 2016), fractionation of bioactive peptides from whey (Baldasso et al., 2011), the enzyme recovery from solutions (Arrutia et al., 2016; Lemmer et al., 2015), the production of lactic acid (Keçeci et al., 2015), and the stabilization of different emulsions as well (Wojtyniak et al., 2016; Ruttarattanamongkol et al., 2015). Other applications are as follows: improvement of foaming properties (Sun et al., 2015), stabilization of different whey protein drinks (Le et al., 2016), bacterial production of hyaluronic acid (Wronkowska et al., 2015), improvement of bread properties (Lörincz et al., 2011), not to mention the traditional possibilities such as the production of ordinary whey powder and different whey cheeses (e.g. Ricotta). A complex utilization system of acid whey was presented in the work of Al-Khajafi et al. (1977).

Our objective was the investigation of ultra-filtered lactic acid whey retentate (UFWR) use with low concentration factor in the production of sour cream in order to reduce the amount of whey as wastewater. The low concentration factor of whey can be justified by lower expenses comparing to ultrafiltration with two or three stages of diafiltration or reverse osmosis. Another aim was to explore the effect of UFWR addition (as milk substitute) on the texture and the sensory properties.

\section{Materials and methods}

\subsection{Ultrafiltration}

A simple ultrafiltration was performed in batch system without diafiltration, using VSEP-LP vibration ultrafilter (New Logic Research, Inc., Emeryville, California 94608, USA). Conditions: pressure: 8.0 bar; temperature: $40{ }^{\circ} \mathrm{C}$; membrane: PAN (poli-akril-nitril); cut-off value: $10 \mathrm{kDa}$ (Figure 1). Ultrafiltration was performed using a simple batch system without special pretreatment of lactic acid whey; so, the concentration factor was fairly low (1.8). 


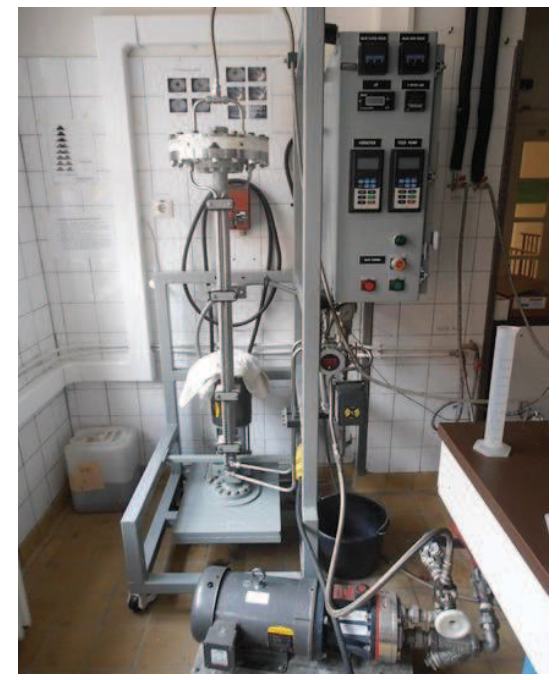

Figure 1: VSEP ultrafilter

\subsection{Chemical investigation}

A Bentley 150 milk analyser (Bentley Instrument Inc. Chaska, Minnesota 55318 USA) was used for the determination of whey composition, ultrafiltered retentate, and permeate at $40^{\circ} \mathrm{C}$. Data were expressed in $\mathrm{m} / \mathrm{m} \%$. The composition of the different experimental media is presented in Table 1. We did not reach remarkable protein increment and lactose was enriched, probably due to the different complex molecule formation.

Table 1: Composition of whey, permeate, and UF retentate $(\mathrm{m} / \mathrm{m} \%$; concentration factor: 1.8$)$

\begin{tabular}{lccccc}
\hline & Fat & True protein & Crude protein & Lactose & Total solids \\
\hline Whey (Feed) & 0.15 & 0.59 & 0.90 & 3.67 & 6.49 \\
Permeate & 0.40 & 0.49 & 0.63 & 3.27 & 5.61 \\
Retentate & 0.44 & 0.88 & 1.32 & 5.52 & 8.66 \\
\hline
\end{tabular}




\subsection{Experimental sour cream making}

After the addition of different percentages $(2 \%, 5 \%, 10 \%)$ of UFWR into milk (without $\mathrm{pH}$ buffering) and after fat standardization to $16 \mathrm{~m} / \mathrm{m} \%$, the cream was heated to $60^{\circ} \mathrm{C}$ for homogenization at 150 bar pressure with Gaulin Lab 60 homogenizer (Graafdijk-Oost 23, 2973 XB, Molenaarsgraaf, Netherlands) (Figure 2). Then, the homogenized cream was pasteurized at $72^{\circ} \mathrm{C}$ with oneminute holding time, and then it was cooled to $26^{\circ} \mathrm{C}$ for inoculation.

(A)
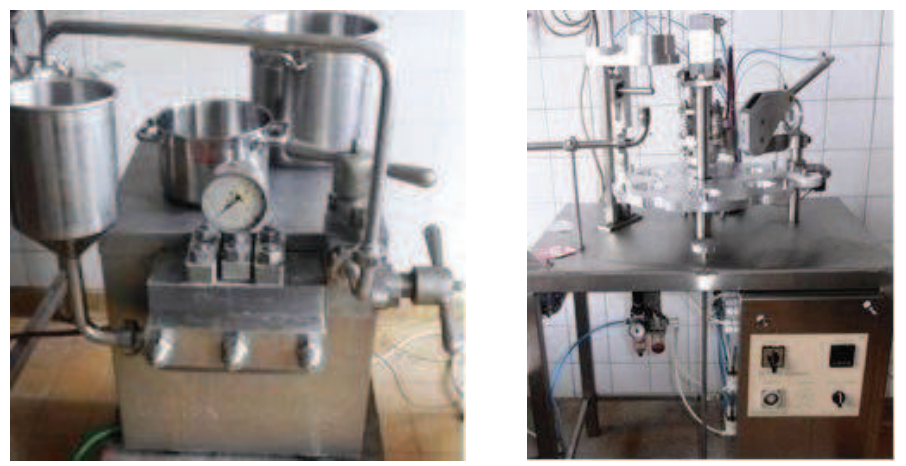

Figure 2: The homogenizer (A) and the packaging machine (B)

The gentle pasteurization condition is explained by the heat sensitivity of whey proteins fortified in cream. Inoculation rate was $2 \mathrm{ml} / 3000 \mathrm{ml}$ cream, from a $20 \%$ culture solution using DI-PROX ${ }^{\circledR}$ M 272 freeze-dried starter (Bioprox Ltd. 92532 Levallois-Perret Cedex, France). Then, different samples were packed in cups with a semi-automatic packaging machine (Junior Handy type, Zootechnika Ltd. Gödöllö, Hungary). After packaging, the samples were fermented in a thermostat (Labor MIM, Hungary) at $26^{\circ} \mathrm{C}$ for reaching $4.6 \mathrm{pH}$ measured with Orion 4Star instrument (Thermo Fischer Scientific Inc., Singapore). Then, samples were cooled in a refrigerator and were stored until the investigations.

\subsection{Texture properties}

Brookfield LFRA CT3 texture analyser (Brookfield Engineering Laboratories, Inc., Middleboro, Massachusetts, USA, 02346) was used for the determination of hardness, adhesiveness, and adhesive force of sour cream samples. Measuring conditions: simple compression test was used with a 12-mm-diameter plastic cylinder (penetration target: $20 \mathrm{~mm}$; penetration force: $50 \mathrm{mN}$; speed: 
$0.5 \mathrm{~mm} / \mathrm{s}$ ). Measures were performed in three replicates using five parallel samples. Every sample was measured in three places of the surface.

\subsection{Whey leakage ratio}

Whey leakage was determined with the method published in the work of $\mathrm{Al}$ Khajafi et al. (1977). First, a 40-mm-diameter semi-sphere was cut into the surface of the curd; then, after one hour, the weight of the accumulated whey was measured. Less amount of whey (higher water-binding capacity) means better texture.

\subsection{Sensory evaluation}

Sensory evaluation was performed by ten persons using Hungarian Standard 12253-84. Part of the sensory evaluation was the comparison of experimental samples to the control samples $-20 \%$ fat content - made in a dairy firm.

\section{Results and discussions}

\subsection{Whey leakage}

The measured whey leakage values (Table 2.) were high, considering the classification method in Al-Khajafi et al. (1977) $(<0.5 \mathrm{ml}, 0.5-1.0 \mathrm{ml},>2.0 \mathrm{ml})$. E.g. the low pasteurizing temperature and the slow heating rate can be explained with the experimental condition of making sour cream samples.

Table 2: Whey leakage of sour cream samples (means; $\mathrm{g} ; \mathrm{n}=45$ )

\begin{tabular}{ccccc}
\hline \multirow{2}{*}{$\begin{array}{c}\text { Whey ratio } \\
(\%)\end{array}$} & \multicolumn{3}{c}{ Repetitions } & \multirow{2}{*}{ Average } \\
\cline { 2 - 4 } & First & Second & Third & \\
\hline 2 & 5.35 & 5.62 & 5.47 & 5.48 \\
5 & 2.09 & 2.83 & 2.38 & 2.38 \\
10 & 4.08 & 4.12 & 4.08 & 4.09 \\
\hline
\end{tabular}

The explored differences demonstrate that whey proteins can play an important role in the water-binding capacity of lactic acid gels such as sour cream. Interestingly, the higher whey retentate ratio reduced the whey leakage first, while a more than $5 \%$ ratio yielded worse result. This is explained by the 
higher dilution ratio of cream with UF whey retentate, maybe because of its lower crude protein content compared to cream (1.94-2.01\%). Higher ratio of UF whey retentate resulted lower protein content in the cream-UF retentate mixture than the dilution in lower ratio. The $5 \%$ UFWR ratio was the optimal in our experiments.

\subsection{Texture analysis}

Significant difference $((\mathrm{p} \leq 0.05)$; using Statistica 12 for MS Windows software) was revealed between the samples made with $2 \%$ and $5 \%$ added UF whey retentate and also between the samples' $2 \%$ and $10 \%$ UF retentate-added samples (Figure 3).

But the difference was not significant between the samples made with $5 \%$ and $10 \%$ UFWR addition. The higher values of investigated texture properties are explained by the higher amount of denatured whey proteins built into the casein protein matrix during the lactic acid clotting.

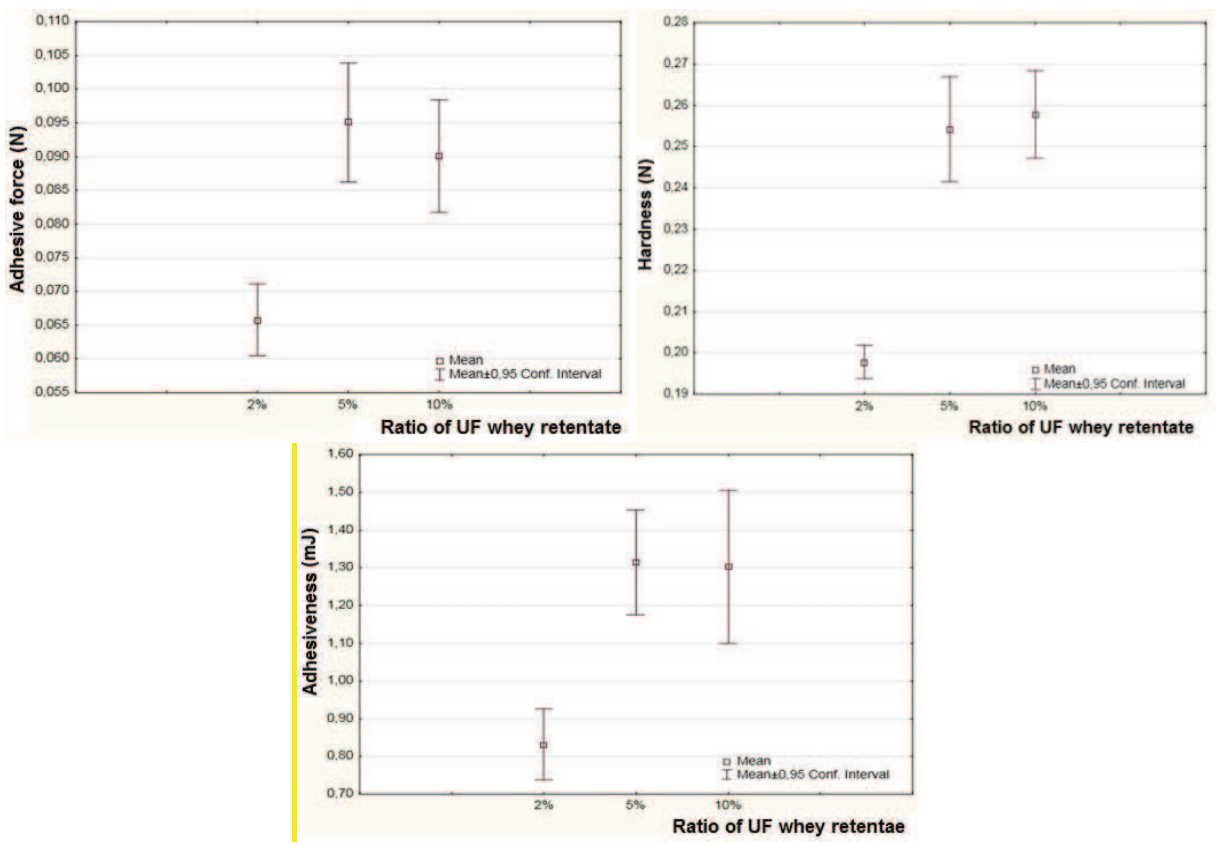

Figure 3: Texture properties of different samples made with UF whey retentate $(\mathrm{n}=45)$ 
The lack of further improvement in these properties can be explained by the lower relative ratio of casein in the mixture containing a higher ratio of UF whey retentate. As the aggregation between denatured whey proteins and casein micelles can improve texture properties, the lower casein content in the mixture can compensate this beneficial consequence. As Figure 4 shows, the control sample gave slightly better results. It is explained by higher fat content $(20 \%)$ and the industrial processing condition. However, the results of samples made with the addition of $5 \%$ and $10 \%$ UF whey retentate were close to those of the control ones.

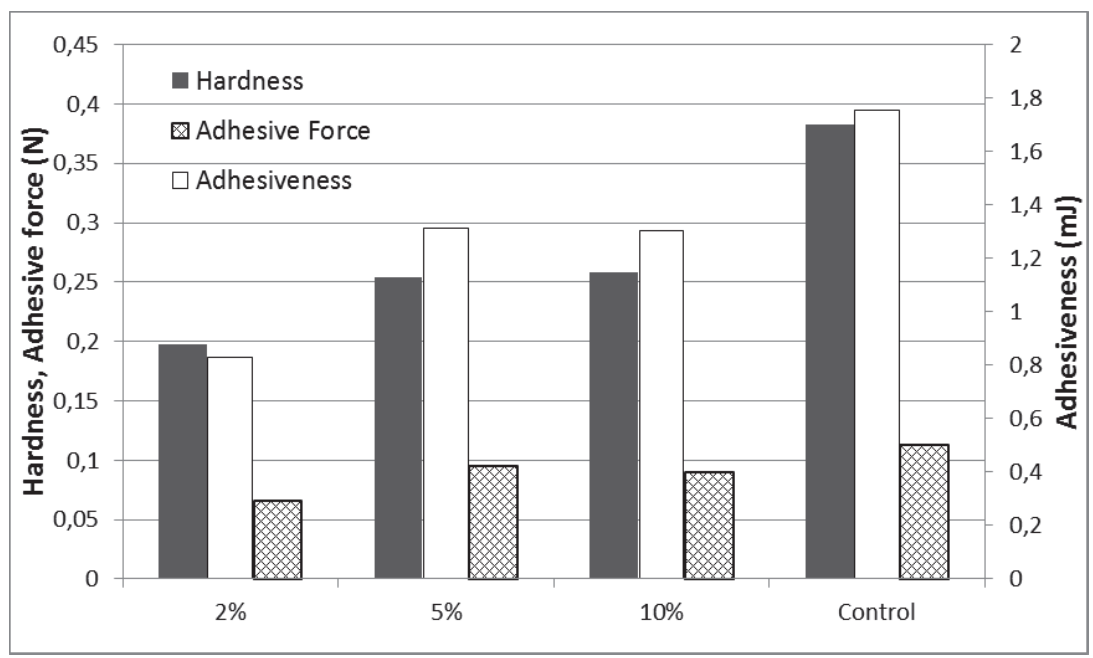

Figure 4: Comparison of texture properties of experimental and control samples $(n=10)$

\subsection{Sensory evaluation}

The sensory evaluation showed markedly different results compared to the results from texture analysis. Higher UFWR addition resulted worse judgement of experimental samples (Figure 5). Especially samples made with the highest UFWR addition got unsavoury characteristics.

We can confirm that the special sensory property of whey, especially of lactic acid whey, limit further direct utilization. Higher ratio of UFWR addition resulted worse scores in all replicates, except for smell. The sample made with $10 \%$ UFWR addition yielded the worst score (12.5 points), so this experimental product cannot be marketed. 


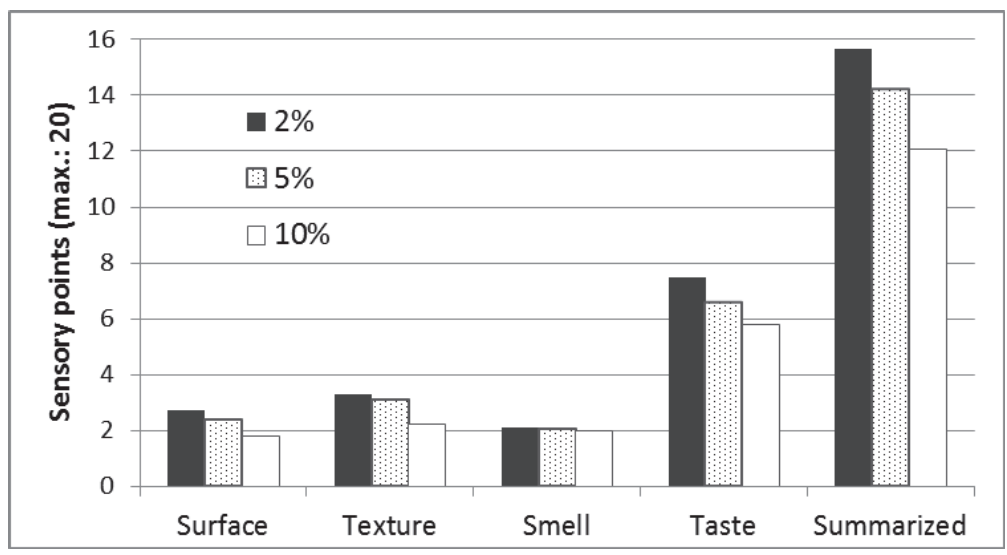

Figure 5: Sensory evaluation of samples with UF whey retentate addition

\section{Conclusion}

The addition of UFWR into cream can be a form of utilization of this dairy side-product. We investigated the use of UFWR from a single-batch ultrafiltration in order to limit further processing costs. We did not achieve enough high protein content in retentate and because of mild sensory properties of experimental samples our mixtures did not result a real, satisfactory solution. Although the texture properties of experimental samples were improved (5\% UFWR addition gave the best result), the sensory scores decreased with the increase of UFWR addition. Based on the sensory evaluation, the limit of the addition of UF lactic acid whey retentate from a single-batch ultrafiltration is $5 \%$. Further investigation is needed to find the optimal composition and sensory properties of whey UFWR using diafiltration. Furthermore, we have to perform a technological investigation to reach a higher concentration factor using pre-treatment of whey and to avoid the precipitation of whey proteins during the high temperature pasteurization of cream, cream mixed with UFWR, or diafiltered whey retentates. We guess that the use of onestage diafiltration would already decrease the unfavourable sensory properties of lactic acid whey retentate. 


\section{References}

[1] T. Malkovic, Process turns waste whey into profitable products. ScienceNetwork Wa; http://phys.org/news/2015-10-whey-profitableproducts.html (October 27, 2015).

[2] F. Squadrito, D. Altavilla, G. Squadrito, A. Saitta, D. Cucinotta, L. Minutoli, B. Deodato, M. Ferlito, G. M. Campo, A. Bova, A. P. Caputi, Genistein supplementation and estrogen replacement therapy improve endothelial dysfunction induced by ovariectomy in rats, Cardiovasc. Res., 45. (2000) 454-462.

[3] E. Ha, M. B. Zemel, Functional properties of whey, whey components, and essential amino acids: mechanisms underlying health benefits for active people, J. Nutr. Biochem., 14. (2003) 251-258.

[4] S. J. Bhathena, M. T. Velasquez, Beneficial role of dietary phytoestrogens in obesity and diabetes, Am. J. Clin. Nutr., 76. (2002) 1191-1201.

[5] L. Seppo, T. Jauhiainen, T. Poussa, R. Korpela, A fermented milk high in bioactive peptides has a blood pressure lowering effect in hypertensive subjects, Am. J. Clin. Nutr., 77. (2003) 326-330.

[6] A. Hayes, P. J. Cribb, Effect of whey protein isolate on strength, body composition and muscle hypertrophy during resistance training, Curr. Opin. Clin. Nutr. Metab. Care, 11. (2008) 40-44.

[7] P. Fanti, R. Asmis, T. J. Stephenson, B. P. Sawaya, A. A. Franke, Positive effect of dietary soy in ESRD patients with systemic inflammation and correlation between blood levels of the soy isoflavones and the acute-phase reactants, Nephrol. Dial. Transplant., 21. (2006) 2239 2246 .

[8] Q. Chen, R. A. Reimer, Dairy protein and leucine alter GLP-1 release and mRNA of genes involved in intestinal lipid metabolism in vitro, Nutrition, 25. (2009) 340-349.

[9] A. Tahavorgar, M. Vafa, F. Shidfar, M. Gohari, I. Heydari, Beneficial effects of whey protein preloads on some cardiovascular diseases risk factors of overweight and obese men are stronger than soy protein preloads - A randomized clinical trial. J. of Nutrition \& Int. Met., 2. (2015) 69-75. 
[10] J. G. Brennan, A. S., Grandison, M. J. Lewis, Separations in food processing. In: J. G. Brennan (ed.), Food Processing Handbook, WileyVCH, Weinheim. (2006) 429-511.

[11] P. Walstra, J. T. M. Wouters, T. J. Geurts, Dairy Science and Technology. Taylor \& Francis, 6000 Broken Sound Parkway NW, Suite 300 Boca Raton, FL 33482-2742. (2006).

[12] A. Román, J. Wang, J. Csanádi, C. Hodúr, Gy. Vatai, Partial demineralization and concentration of acid whey by nanofiltration combined with diafiltration. Desalination, 241. (2009) 288-295.

[13] C. Hodúr, Sz. Kertész, J. Csanádi, G. Szabó, Comparison of 3DTA and VSEP systems during the ultrafiltration of sweet whey. Desal. and Water Treatm., 10. (2010) 265-271.

[14] Sz. Szélpál, Zs. Kohány, E. Fogarassy, J. Csanádi, Gy. Vatai, C. Hodúr, Assaying of the filtration parameters of whey by different filtration systems. Acta Technica Corviniensis - Bulletin of Engineering, 7. (2014) $127-31$.

[15] E. Schwinden Prudencio, C. M. O. Müller, C. B. Fritzen-Freire, R. D. M. Castanho Amboni, J. C. Cunha Petrus, Effect of whey nanofiltration process combined with diafiltration on the rheological and physicochemical properties of ricotta cheese. Food Res. Int., 56. (2014) 92-99.

[16] G. Q. Chen, F. I. I. Eschbach, M. Weeks, S. L. Gras, S. E. Kentish, Removal of lactic acid from acid whey using electrodialysis. Sep. and Pur. Techn., 158. (2016) 230-237.

[17] Sz. Kertész, A. Szép, J. Csanádi, G. Szabó, C. Hodúr, Comparison between stirred and vibrated UF modules, Desal. and Water Treatm., 14. (2010) 239-245.

[18] N. C. Gajendragadkar, P. R. Gogate, Intensified recovery of valuable products from whey by use of ultrasound in processing steps - A review. Ultrasonics Sonochem., 32. (2016) 102-118.

[19] M. C. Almecija, A. Guadix, A. Martinez-Ferez, P. Gonzalez-Tello, E. M. Guadix, A flux enhancing pretreatment for the ultrafiltration of acid whey. Desalination, 245. (2009) 737-742. 
[20] M-J. Corbatón-Báguena, S. Álvarez-Blanco, M-C. Vincent-Vela, E. Ortega-Navarro, V. Pérez-Herranz, Application of electric fields to clean ultrafiltration membranes fouled with whey model solutions. Sep. and Pur. Techn., 159. (2016) 92-99.

[21] A. Román, J. Wang, J. Csanádi, C. Hodúr, Gy. Vatai, Experimental investigation of the sweet whey concentration by nanofiltration. Food and Bioprocess Techn., 4. (2011) 702-709.

[22] J. Chandrapala, M. C. Duke, S. R. Gray, M. Weeks, M. Palmer, T. Vasiljevic, Nanofiltration and nanodiafiltration of acid whey as a function of pH and temperature. Sep. and Pur. Techn., 160. (2016) 18-27.

[23] C. Baldasso, T. C. Barros, I. C. Tessaro Baldasso, Concentration and purification of whey proteins by ultrafiltration. Desalination, 278 . (2011) 381-386.

[24] F. Arrutia, R. Rubio, F. A. Riera, Production and membrane fractionation of bioactive peptides from a whey protein retentate. J. of Food Eng. (article in press), (2016) 1-9.

[25] B. Lemmer, K. Keçeci, Sz. Kertész, Zs. László, C. Hodúr, Szonikációval segített enzim-visszanyerés. Membrántechnika és Ipari Biotechnológia, 6. (2015) 42-51.

[26] K. Keçeci, B. Lemmer, Sz. Kertész, G. Keszthelyi-Szabó, Zs. László, C. Hodúr, The effect of the implementation of ultrasound in enzyme separation. Review of Faculty of Engineering. Analecta Technica Szegedinensia (online), 9. (2015) 34-41.

[27] B. Wojtyniak, J. Kołodziejczyk, D. Szaniawska, Production of lactic acid by ultrafiltration of fermented whey obtained in bioreactor equipped with ZOSS membrane. Chemical Eng. J. (article in press) (2016).

[28] K. Ruttarattanamongkol, M. Nor Afizah Syed, S. H. Rizvi, Stability and rheological properties of corn oil and butter oil emulsions stabilized with texturized whey proteins by supercritical fluid extrusion. $J$. of Food Eng., 166. (2015) 139-147.

[29] C. Sun, T. Wu, R. Liu, B. Liang, Z. Tian, E. Zhang, M. Zhang, Effects of superfine grinding and microparticulation on the surface hydropho- 
bicity of whey protein retentate and its relation to emulsions stability. Food Hydrocolloids, 51. (2015) 512-518.

[30] L. P. Martínez-Padilla, V. García-Mena, N. B. Casas-Alencáster, M. G. Sosa-Herrera, Foaming properties of skim milk powder fortified with milk proteins. Int. Dairy J., 36. (2014) 21-28.

[31] T. T. Le, S. D. Nielsen, N. S. Villumsen, G. H. Kristiansen, L. R. Nielsen, S. B. Nielsen, M. Hammershoj, L. B. Larsen, Using proteomics to characterise storage-induced aggregates in acidic whey protein isolate drinks. Int. Dairy J. (article in press), (2016) 1-8.

[32] I. R. Amado, J. A. Vázquez, L. Pastrana, J. A. Teixeira, Cheese whey: A cost-effective alternative for hyaluronic acid production by Streptococcus zooepidemicus. Food Chem., 198. (2016) 54-61.

[33] M. Wronkowska, M. Jadacka, M. Soral-Smietana, L. Zander, F. Dajnowiec, P. Banaszczyk, T. Jelinski, B. Szmatowicz, Acid whey retentated by ultrafiltration a tool for modeling bread properties. LWT Food Sci. and Techn., 61. (2015) 172-176.

[34] A. Lőrincz, A. Unger, Á. Novák, K. Szabó, G. Császár, S. Bukovics, A. Fülöp, Cs. Balla, L. Friedrich, H. K. Pásztorné, L. Szalai, Kutatások a savanyú savó alkotórészeinek membránszeparációs technikákkal történő teljes körủ hasznosítására. (Researches for the whole utilization of lactic acid whey by membrane filtration techniques). Hungarian Dairy Journal. Science and Practice (Tejgazdaság), 71. (2011) 30-33.

[35] M. Al-Khajafi, S. Szakály, J. Schrem, Egyszerü gyors módszerek a savanyú tejtermékek állománytulajdonságainak mérésére. (Simple tests for the determination of texture properties of fermented milk products). Dairy Industry (Tejipar), 27. (1977) 12-17. 